\title{
Front Matter: Volume 9491
}

, "Front Matter: Volume 9491," Proc. SPIE 9491, Sensors for Extreme Harsh Environments II, 949101 (28 May 2015); doi: 10.1117/12.2199541

SPIE Event: SPIE Sensing Technology + Applications, 2015, Baltimore, MD, United SPIE. States 


\title{
PROCEEDINGS OF SPIE
}

\section{Sensors for Extreme Harsh Environments II}

\author{
Debbie G. Senesky \\ Sachin Dekate \\ Editors
}

22-23 April 2015

Baltimore, Maryland, United States

Sponsored and Published by

SPIE 
The papers included in this volume were part of the technical conference cited on the cover and title page. Papers were selected and subject to review by the editors and conference program committee. Some conference presentations may not be available for publication. The papers published in these proceedings reflect the work and thoughts of the authors and are published herein as submitted. The publisher is not responsible for the validity of the information or for any outcomes resulting from reliance thereon.

Please use the following format to cite material from this book:

Author(s), "Title of Paper," in Sensors for Extreme Harsh Environments II, edited by Debbie G. Senesky, Sachin Dekate, Proceedings of SPIE Vol. 9491 (SPIE, Bellingham, WA, 2015) Article CID Number.

ISSN: 0277-786X

ISBN: 9781628416077

Published by

SPIE

P.O. Box 10, Bellingham, Washington 98227-0010 USA

Telephone +1 3606763290 (Pacific Time) · Fax +1 3606471445

SPIE.org

Copyright (C) 2015, Society of Photo-Optical Instrumentation Engineers.

Copying of material in this book for internal or personal use, or for the internal or personal use of specific clients, beyond the fair use provisions granted by the U.S. Copyright Law is authorized by SPIE subject to payment of copying fees. The Transactional Reporting Service base fee for this volume is $\$ 18.00$ per article (or portion thereof), which should be paid directly to the Copyright Clearance Center (CCC), 222 Rosewood Drive, Danvers, MA 01923. Payment may also be made electronically through CCC Online at copyright.com. Other copying for republication, resale, advertising or promotion, or any form of systematic or multiple reproduction of any material in this book is prohibited except with permission in writing from the publisher. The CCC fee code is 0277-786X/15/\$18.00.

Printed in the United States of America.

Publication of record for individual papers is online in the SPIE Digital Library.

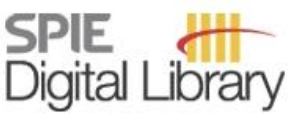

SPIEDigitalLibrary.org

Paper Numbering: Proceedings of SPIE follow an e-First publication model, with papers published first online and then in print. Papers are published as they are submitted and meet publication criteria. A unique citation identifier (CID) number is assigned to each article at the time of the first publication. Utilization of CIDs allows articles to be fully citable as soon as they are published online, and connects the same identifier to all online, print, and electronic versions of the publication. SPIE uses a six-digit CID article numbering system in which:

- The first four digits correspond to the SPIE volume number.

- The last two digits indicate publication order within the volume using a Base 36 numbering

system employing both numerals and letters. These two-number sets start with $00,01,02,03$,

$04,05,06,07,08,09,0 A, 0 B \ldots .0 Z$, followed by 10-1Z, 20-2Z, etc.

The CID Number appears on each page of the manuscript. The complete citation is used on the first page, and an abbreviated version on subsequent pages. 


\title{
Contents
}

\author{
$\checkmark$ Authors \\ vii Conference Committee
}

\section{MICRO/NANO SENSING TECHNOLOGY FOR HARSH ENVIRONMENTS}

949104 Growth and morphology of lead tin selenide for MWIR detectors [9491-2]

949107 Irradiation effects of graphene-enhanced gallium nitride (GaN) metal-semiconductormetal (MSM) ultraviolet photodetectors [9491-5]

949108 Investigation of the optical and sensing characteristics of nanoparticle arrays for high temperature applications [9491-6]

949109 Wireless photonic power and data transfer to dormant devices [9491-7]

\section{OPTICAL SENSING TECHNOLOGY FOR HARSH ENVIRONMENTS I}

9491 OA Characterization and calibration of Raman based distributed temperature sensing system for $600^{\circ} \mathrm{C}$ operation [9491-8]

\section{OPTICAL SENSING TECHNOLOGY FOR HARSH ENVIRONMENTS II}

9491 OD Optical sensors for harsh environment applications [9491-11]

$9491 \mathrm{OE}$ Analysis of the acoustic response in water and sand of different fiber optic sensing cables [9491-12]

9491 OF Distributed temperature and distributed acoustic sensing for remote and harsh environments [9491-13]

9491 OG Planetary atmospheres minor species sensor balloon flight test to near space [9491-14]

$9491 \mathrm{OH} \quad$ Optical fiber reliability in subsea monitoring [9491-16]

POSTER SESSION

949101 Thermal stability and energy harvesting characteristics of Au nanorods: harsh environment chemical sensing [9491-17]

9491 0J Microfabricated electrochemical sensors for combustion applications [9491-18]

9491 OK Data communication through multiple physical media: applications to munitions [9491-19] 
Proc. of SPIE Vol. $9491949101-4$

Downloaded From: https://www.spiedigitallibrary.org/conference-proceedings-of-spie on 25 Apr 2023 Terms of Use: https://www.spiedigitallibrary.org/terms-of-use 


\section{Authors}

Numbers in the index correspond to the last two digits of the six-digit citation identifier (CID) article numbering system used in Proceedings of SPIE. The first four digits reflect the volume number. Base 36 numbering is employed for the last two digits and indicates the order of articles within the volume. Numbers start with 00, 01, 02, 03, 04, 05, 06, 07, 08, 09, 0A, 0B...0Z, followed by 10-1Z, 20-2Z, etc.

Arnold, Bradley, 04

Balasubramaniam, Mahadevan, $\mathrm{OH}$

Bekal, A., OD

Bode, Rolfe, OG

Broad, Nicholas, 07

Calhoun, Seth, OG

Carpenter, Michael A., 08, 0I, 0J

Chiamori, Heather C., 07

Choa, Fow-Sen, 04

Coleman, Thomas, OF

Colwell, Joshua E., OG

Cooper, Christopher, 04

Dekate, Sachin, $\mathrm{OA}, \mathrm{OH}$

Dewey, Russell G., OG

Dhadwal, Harbans S., 09, OK

Dharmalingam, Gnanaprakash, 08, 0l

Dutta, Prabir K., OJ

Facchini, Massimo, OE

Farhadiroushan, Mahmoud, OF

Feng, Dake, 09, OK

Fredricksen, Christopher J., OG

Goranson, Marc, OA

Guida, Renato, OA

Hofmann, Joachim, OE

Karker, Nicholas A., OI, OJ

Koste, Glenn, $\mathrm{OH}$

Kowarz, Marek W., OJ

Kwok, Philip, 09, OK

Lachenmeier, Timothy A., OG

Lee, Boon K., OA

Lowell, Mark, OE

Maity, S., OD

Mandal, Sudeep, $\mathrm{OA}, \mathrm{OH}$

Maukonen, Douglas, OG

Miller, Ruth, 07

Milne, Craig H., OF

Mitra, C., OD

Mondanos, Michael, OA, OF

Mullen, Max R., 0J

Muraviev, Andrei $\mathrm{V}_{\text {., }}$ OG

Nagarkar, Kaustubh, $\mathrm{OH}$

Ostroverkhov, Victor, $\mathrm{OH}$

Padilla, Sebastian, 0G

Parker, Tom, OF

Peale, Robert E., OG

Prasad, Narasimha, 04

Quddusi, Hajrah M., OG

Rastegar, Jahangir, 09, OK

Rubinsztajn, Slawomir, $\mathrm{OH}$
Schultheis, Emily, 04

Senesky, Debbie G., 07

Sharma, R., OD

Singh, N. B., 04

Sridharan, A. K., OD

Stecher, Thomas, $\mathrm{OH}$

Stern, Alan, OG

Strobbia, Pietro, 04

Suria, Ateeq, 07

Vartak, S., OD

Vulcano Rossi, Vitor A., OJ

Yeo, Jackson, OA, OF

Zhao, Zhouying, $0 \mathrm{~J}$ 
Proc. of SPIE Vol. $9491949101-6$

Downloaded From: https://www.spiedigitallibrary.org/conference-proceedings-of-spie on 25 Apr 2023 Terms of Use: https://www.spiedigitallibrary.org/terms-of-use 


\section{Conference Committee}

Symposium Chair

Wolfgang Schade, Clausthal University of Technology and Fraunhofer Heinrich-Hertz Institute (Germany)

Symposium Co-chair

Ming C. Wu, University of California, Berkeley (United States)

Conference Chairs

Debbie G. Senesky, Stanford University (United States)

Sachin Dekate, GE Global Research (United States)

Conference Program Committee

Laurent A. Francis, Université Catholique de Louvain (Belgium)

Jr-Hau (J.H.) He, King Abdullah University of Science and Technology (Saudi Arabia)

Kevin S. C. Kuang, National University of Singapore (Singapore)

Session Chairs

1 Novel Harsh Environment Sensors for Energy Applications: Joint Session with Conferences 9467 and 9491

Michael P. Buric, National Energy Technology Laboratory (United States)

2 Micro/Nano Sensing Technology for Harsh Environments

Debbie G. Senesky, Stanford University (United States)

3 Optical Sensing Technology for Harsh Environments I Sudeep Mandal, GE Global Research (United States)

4 Optical Sensing Technology for Harsh Environments II Sudeep Mandal, GE Global Research (United States) 
Proc. of SPIE Vol. $9491949101-8$

Downloaded From: https://www.spiedigitallibrary.org/conference-proceedings-of-spie on 25 Apr 2023 Terms of Use: https://www.spiedigitallibrary.org/terms-of-use 